\title{
DISINTERMEDIASI FUNGSI PERBANKAN DI INDONESIA PASCA KRISIS 1997 : \\ Faktor Permintaan Atau Penawaran Kredit, Sebuah Pendekatan Dengan Model Disequilibrium
}

\author{
Harmanta, ME \\ Dr. Mahyus Ekananda'
}

\begin{abstract}
The goal of this paper is to analyze the determinants of bank credit declining, whether is dominated by the supply or the credit demand, post the financial crisis in Indonesia. This paper is a sort of New Keynesian approach, which pre assume the imperfectness of the credit market and hence create disequilibrium.

Using the switching regression model and Maximum Likelihood Estimation to determine the probability of supply or demand determination, the result shows the existence of excess demand of credit during the crisis period, 1997/ 1998, confirming the credit crunch situation. After the crisis, the condition is reversed, where the credit supply is higher than the credit demand. The two findings implicitely shows the inflexibility of interest rate to equalize the credit market.
\end{abstract}

JEL: D43, D82, E44, E51

Keywords: Disintermediasi, kredit, disequilibrium, maximum likelihood, persamaan simultan, switching regression

1 Hermanta adalah alumnus Program Magister Perencanaan dan Kebijakan Publik, FE-UI dan peneliti pada Direktorat Pengelolaan Moneter, Bank Indonesia, harmanta@bi.go.id. Mahyus Ekananda adalah Dosen Program Pasca Sarjana FE-UI, m_ekananda@yahoo.com 


\section{PENDAHULUAN}

Sebagaimana umumnya negara berkembang, sumber utama pembiayaan investasi di Indonesia masih didominasi oleh penyaluran kredit perbankan. Dengan demikian wajar apabila melambatnya penyaluran kredit perbankan di Indonesia setelah krisis 1997 dituding sebagai salah satu penyebab lambatnya pemulihan ekonomi Indonesia dibandingkan negara Asia lainnya yang terkena krisis (Korea Selatan dan Thailand). Meskipun kondisi makroekonomi dalam beberapa tahun terakhir relatif membaik, tercermin dari terkendalinya laju inflasi, stabilnya nilai tukar, dan turunnya suku bunga, namun kredit yang disalurkan perbankan belum cukup menjadi mesin pendorong pertumbuhan ekonomi untuk kembali pada level sebelum krisis, yang berarti bahwa fungsi intermediasi perbankan masih belum pulih atau terjadi disintermediasi perbankan.

Laporan Bank Indonesia² menunjukkan bahwa belum pulihnya fungsi intermediasi perbankan antara lain disebabkan oleh masih berlangsungnya konsolidasi internal perbankan dan belum mampunya sektor riil menyerap kredit. Belum selesainya proses restrukturisasi kredit telah menimbulkan potensi meningkatnya Non Performing Loans (NPLS) ${ }^{3}$. Sementara itu, konsolidasi internal perbankan seperti penerapan good corporate governance dan pengelolaan risiko yang baik masih merupakan proses yang dilaksanakan oleh perbankan. Semua hal tersebut sangat dicermati oleh perbankan karena pengaruhnya pada kecukupan modal perbankan atau CAR (Capital Adequacy Ratio). Di sisi lain, dalam kondisi resesi ekonomi setelah krisis, penurunan kredit perbankan dapat juga terjadi karena melemahnya permintaan kredit dari sektor swasta akibat rendahnya prospek investasi dan belum pulihnya kondisi keuangan perusahaan.

Studi literatur menunjukkan bahwa sebab-sebab menurunnya penyaluran kredit perbankan kepada sektor swasta di Asia setelah krisis tahun 1997 masih menimbulkan perdebatan di antara para ekonom (Agenor, dkk., 2000)4. Sebagian ekonom berpendapat bahwa menurunnya penyaluran kredit perbankan disebabkan oleh "credit crunch" yang menimbulkan fenomena credit rationing sehingga terjadi penurunan penawaran kredit oleh perbankan (supply side constraint). Ekonom yang lain berargumentasi bahwa menurunnya penyaluran kredit perbankan lebih disebabkan oleh menurunnya permintaan terhadap kredit (demand side constraint) sebagai konsekuensi logis terjadinya kontraksi permintaan agregat (aggregate demand) dan turunnya output setelah krisis.

2 Bank Indonesia. Juni 2003. Perbankan Indonesia Tahun 2002. Bank Indonesia, Jakarta.

3 Dilihat dari sisi kolektibilitasnya kredit digolongkan sebagai NPL kalau kurang lancar, diragukan dan macet berdasarkan ketentuan Bank Indonesia tentang Kualitas Aktiva Produktif.

4 Agenor, P.R., J. Aizenman, dan A. Hoffmaister. 2000. The Credit Crunch in East Asia : What Can Bank Excess Liquid Assets Tell Us?. NBER, Inc., Cambridge. Working Paper 7951. October 2000. 
Menurut Agenor, dkk. (2000), penyebab menurunnya penyaluran kredit perbankan apakah berasal dari faktor permintaan kredit atau faktor penawaran kredit mempunyai implikasi penting terhadap kebijakan fiskal dan moneter. Misalkan, jika bank enggan menyalurkan kredit karena merasa naiknya risiko kegagalan yang tidak dapat diinternalisasi dengan kenaikan biaya peminjaman, maka kebijakan fiskal untuk mencoba memperbesar likuiditas guna menstimulasi permintaan agregat tidak akan efektif meningkatkan permintaan kredit. Sebaliknya, jika rendahnya penyaluran kredit disebabkan sektor usaha mengurangi permintaan terhadap kredit karena merasa lemahnya permintaan di masa datang (demand side), kebijakan fiskal ekspansi mungkin dapat mendorong permintaan agregat dan ekspansi kredit. Dari sisi kebijakan moneter, terjadinya credit crunch karena enggannya perbankan menyalurkan kredit menyebabkan kebijakan moneter yang relatif longgar tidak dapat ditransmisikan ke sektor riil melalui pemberian pinjaman. Selain itu, credit crunch juga dapat mengurangi ruang gerak bagi kebijakan moneter, karena dalam kondisi yang demikian kebijakan moneter yang menaikkan suku bunga akan memperparah kondisi dunia usaha.

Berdasarkan latar belakang tersebut di atas, studi ini mengkaji faktor-faktor yang menyebabkan menurunnya penyaluran kredit perbankan di Indonesia pasca krisis moneter 1997 apakah lebih dipengaruhi oleh faktor penawaran kredit atau oleh permintaan kredit melalui analisis empiris. Mengetahui faktor-faktor penyebab menurunnya penyaluran kredit perbankan tersebut sangat penting karena mempunyai implikasi tertentu terhadap kebijakan ekonomi (fiskal, moneter, sektor riil). Analisis empiris dilakukan secara agregat yaitu terhadap total kredit yang disalurkan Bank Umum ${ }^{5}$.

Maksud dari penelitian ini adalah memberikan sumbangan studi empiris terhadap fenomena disintermediasi fungsi perbankan di Indonesia pasca krisis 1997 dengan menggunakan model dasar disequilibrium framework. Asumsi model disequilibrium framework adalah pasar kredit tidak selalu dapat menyeimbangkan antara permintaan kredit dan penawaran kredit melalui invisible hand (suku bunga kredit) yang antara lain disebabkan oleh informasi pasar kredit yang tidak simetris (assymetric information) ${ }^{6}$. Pendekatan ekonometrik yang digunakan untuk menguji model disequilibrium framework tersebut didasarkan atas studi yang dilakukan oleh Fair dan Kelejian (1974)7 , dan Laffont dan Garcia (1977) ${ }^{8}$ yaitu dengan metode maximum likelihood.

5 Bank Umum di Indonesia terdiri dari Bank BUMN (Persero), Bank Umum Swasta Nasional (BUSN), Bank Pembangunan Daerah (BPD), dan Bank Asing \& Campuran

6 Uraian lebih detil mengenai disequilibrium dan assymetric information dalam pasar kredit antara lain dapat dilihat pada tulisan Stiglitz, J.E. dan A. Weiss (1981), dan Bester, Helmut (1985).

7 Fair, R.C. dan H.H. Kelejian. Methods of Estimation for Markets in Disequilibrium : A Further Study. Econometrica, Vol.42, No.1, Januari 1974, hlm 177-190.

8 Laffont, J-J., and R. Garcia. 1977. Disequilibrium Econometrics for Business Loans. Econometrica, Vol.45, No.5, Juli 1997, hlm.11871204. 


\section{METODE PENELITIAN}

\section{II.1. Sumber dan Karakteristik Data}

Untuk analisis empiris dalam penelitian ini digunakan data time series bulanan periode Januari 1993 s.d. Desember 2003, sehingga total terdapat 132 observasi (11 tahun x 12 bulan). Data yang digunakan dalam mengestimasi model tersebut adalah data time series variabel makro dan mikro ekonomi. Data dimulai dengan rentang waktu 5 tahun sebelum dan 5 tahun setelah krisis ekonomi tahun 1997/98 dengan pertimbangan untuk melihat perbedaan perilaku penyaluran kredit antara periode sebelum krisis dan setelah krisis. Sumber data yang akan digunakan berasal dari Bank Indonesia, Bursa Efek Surabaya (BEJ), dan Badan Pusat Statistik (BPS). Data yang digunakan adalah data riil yaitu telah memperhitungkan laju inflasi. Berikut ini diuraikan mengenai data apa saja yang digunakan, sumber data, karakteristik data dan cara penghitungan (generate) data sebagai berikut :

- Total kredit yaitu posisi nominal (outstanding) per akhir bulan seluruh kredit yang disalurkan oleh Bank Umum (CRBU). Sumber data berasal dari laporan Bank Indonesia berbagai edisi. Untuk mendapatkan posisi kredit riil maka total kredit dari Bank Umum tersebut dibagi dengan IHK (Indeks Harga Konsumen) dengan formula

$$
\text { CRBU riil }=\mathrm{CRBU} / \mathrm{IHK}
$$

Selanjutnya data kredit riil tersebut digenerate dalam bentuk logaritma.

. Produk Domestik Bruto riil (PDBRIIL) dengan harga konstan tahun 1993 dan data bersifat triwulanan (tidak tersedia dalam bentuk bulanan). Sumber data berasal dari laporan Badan Pusat Statistik (BPS). Untuk memperoleh seri data PDBRIIL bulanan dilakukan interpolasi data triwulanan PDB riil tersebut dengan bantuan program Eviews. Metode interpolasi yang digunakan adalah interpolasi dengan cubic spline. Selanjutnya data PDB riil tersebut digenerate dalam bentuk logaritma.

- Inflasi bulanan (INFLMTM) yang dihitung berdasarkan Indeks Harga Konsumen (IHK) dengan tahun dasar 1996=100 di 43 kota $^{9}$ dengan formula :

$$
\text { INFLMTM }=\{(\text { IHK bulan } \mathrm{t})-(\text { IHK bulan } \mathrm{t}-1)\} /(\text { IHK bulan } \mathrm{t}-1) * 100 \% \text {. }
$$

Sumber data IHK berasal dari laporan-laporan BPS berbagai edisi.

- Suku bunga kredit yaitu suku bunga rata-rata kredit modal kerja (KMK) ${ }^{10}$ dari seluruh Bank Umum (RCRBU). Sumber data suku bunga kredit berasal dari laporan Bank Indonesia berbagai edisi. Suku bunga kredit riil diperoleh dengan formula :

9 Tidak termasuk kota Dili, Timor Timur yang sudah keluar dari Republik Indonesia.

10 Laffont J.J. dan R. Garcia (1977) menyatakan bahwa sebagian besar pinjaman dari bank berjangka waktu pendek, sehingga dalam penelitian ini digunakan suku bunga kredit modal kerja. 


$$
\text { RCRBU riil = RCRBU - inflasi tahunan (INFLYOY) }
$$

- Suku bunga deposito yaitu suku bunga rata-rata deposito berjangka waktu 1 (satu) bulan dari seluruh Bank Umum (RDEPBU). Sumber data suku bunga deposito berasal dari laporan Bank Indonesia. Suku bunga deposito riil diperoleh dengan formula :

$$
\text { RDEPBU riil = RDEPBU }- \text { inflasi tahunan (INFLYOY) }
$$

- Suku bunga Sertifikat Bank Indonesia (RSBI) yaitu suku bunga rata-rata tertimbang SBI berjangka waktu 1 (satu) bulan pada saat lelang SBI di Bank Indonesia. Sumber data suku bunga SBI berasal dari laporan Bank Indonesia. Suku bunga SBI riil diperoleh dengan formula :

$$
\text { RSBI riil = RSBI }- \text { inflasi tahunan (INFLYOY) }
$$

- Spread suku bunga Bank Umum (SPRDBU) diperoleh dengan formula :

$$
\text { SPRDBU }=\text { RCRBU }- \text { RDEPBU }
$$

dimana RCRBU adalah suku bunga kredit bank umum dan RDEPBU adalah suku bunga deposito bank umum.

- Lending capacity atau kapasitas kredit (KAPBU) yang diperoleh dengan formula :

$$
\text { KAPBU }=\text { total pasiva }- \text { cash in valut }- \text { modal }- \text { GWM }
$$

dimana GWM adalah Giro Wajib Minimum. Semua data berasal dari laporan Bank Indonesia. Selanjutnya kapasitas kredit riil diperoleh dengan formula :

$$
\text { KAPBU riil }=\text { KAPBU } / I H K
$$

Kemudian data kapasitas kredit riil tersebut digenerate dalam bentuk logaritma.

- Non Performing Loan (NPL) yang merupakan prosentase jumlah kredit bermasalah (kurang lancar, diragukan, macet) terhadap total kredit dengan formula :

$$
N P L=(\text { kredit bermasalah / total kredit }) * 100 \%
$$

Data asli berupa posisi (outstanding) kredit bermasalah dan total kredit Bank Umum berasal dari laporan Bank Indonesia. 
- Nilai tukar Rupiah terhadap US Dollars (KURS) yaitu rata-rata nilai tengah kurs Rupiah terhadap US Dollar. Sumber data berasal dari laporan Bank Indonesia. Selanjutnya data kurs tersebut digenerate dalam bentuk logaritma.

- Indeks Harga Saham Gabungan (IHSG) yang merupakan indeks harga semua saham yang terdaftar pada Bursa Efek Jakarta (BEJ). Sumber data berasal dari laporan BEJ berbagai edisi. Selanjutnya data IHSG tersebut digenerate dalam bentuk logaritma.

- Variabel dummy krisis (DUMMKRIS) untuk membedakan periode sebelum krisis (DUMMKRIS bernilai 0 dari bulan Januari 1993 s.d. Juni 1997) dengan periode setelah krisis (DUMMKRIS bernilai 1 dari bulan Juli 1997 s.d. Desember 2003).

\section{II.2. Uji Kestasioneran Data}

Dalam penelitian ini digunakan data-data time series. Umumnya data series untuk variabel makro ekonomi bersifat unit root. Sebagaimana dikemukakan Maddala (1989) dalam Ghosh dan Ghosh (1999) kebanyakan dalam literatur model disequilibrium isu-isu mengenai stationarity tidak dibahas secara eksplisit dan model diestimasi pada level. Hal ini dikarenakan estimasi pada first differences akan menyebabkan kehilangan banyak informasi. Estimasi pada level dapat dibenarkan (legitimate) sepanjang determinan penawaran kredit dan permintaan kredit berbentuk vektor kointegrasi.

Ketika membahas data series yang stasioner dan tidak stasioner kita memerlukan tes untuk menguji keberadaan unit root dalam rangka menghindari masalah spurious regression. Apabila suatu variabel mengandung unit root, maka regresi yang melibatkan variabel tersebut dapat mengimplikasikan hubungan ekonomi yang salah. Salah satu cara untuk menguji keberadaan unit root dalam suatu variabel adalah Augmented Dickey Fuller Test (ADF Test). Uji ADF menggunakan koreksi parameter untuk higher order correlation dengan mengasumsikan bahwa series y mengikuti proses AR ( $p$ ) dan melakukan penyesuaian terhadap metodologi pengujian. Pendekatan ADF mengontrol untuk higher order correlation dengan menambah lag dari difference term untuk variabel dependent y di persamaan sebelah kanan dari regresi. Bentuk umum persamaan menjadi:

$$
\Delta y_{t}=\mu+\gamma y_{t-1}+\delta_{1} \Delta y_{t-1}+\delta_{2} \Delta y_{t-2}+\ldots+\delta_{p-1} \Delta y_{t-p+1}+\delta_{p} \Delta y_{t-p}+\varepsilon_{t}
$$

Augmented specification kemudian digunakan untuk menguji hipotesa di bawah ini :

$$
\begin{aligned}
& H_{0}: \gamma=0 \\
& H_{1}: \gamma<0
\end{aligned}
$$


Jika $\mathrm{HO}$ diterima maka berarti series mengandung unit root, dengan kata lain data series bersifat tidak stasioner. Dalam tesis ini uji ADF menggunakan bantuan program Eviews dan nilai kritis yang digunakan adalah MacKinnon Critical Values.

\section{II.3. Spesifikasi Model}

Persoalan utama untuk mengetahui apakah penurunan kredit perbankan pasca krisis lebih disebabkan oleh penawaran kredit atau oleh permintaan kredit adalah bagaimana mengidentifikasi bahwa kredit yang disalurkan perbankan lebih banyak disebabkan oleh faktorfaktor penawaran atau oleh permintaan kredit. Identifikasi ini dilakukan dengan metode "switching regression" untuk memperoleh informasi apakah kredit yang disalurkan dapat dihubungkan dengan fungsi penawaran kredit atau permintaan kredit. Sebagai konsekuensinya model harus mengasumsikan bahwa permintaan kredit tidak selalu sama dengan penawaran kredit (disequilibrium). Metode estimasi yang digunakan adalah dengan Maximum Liklelihood (ML).

Alasan pemilihan metode estimasi ML untuk switching regression terhadap pasar kredit dalam kondisi disequlibrium adalah sebagai berikut :

- sebagaimana ditunjukkan oleh Maddala dan Nelson (1974) dalam Pazarbasioglu (1997), dalam kondisi tidak adanya informasi berkaitan dengan proses penyesuaian harga (suku bunga) dan asumsi bahwa residu merupakan variabel acak yang terdistribusi normal, penggunaan metode estimasi maximum likelihood dengan sendirinya dapat mendeterminasi "probabilitas" setiap observasi kredit aktual apakah lebih ditentukan oleh persamaan penawaran kredit atau oleh permintaan kredit.

- seperti dikemukan oleh Fair dan Jaffee (1972) penggunaan metode estimasi OLS dan TSLS dalam kondisi pasar disequilibrium akan menghasilkan estimasi yang tidak konsisten karena fakta bahwa mean $u_{t}$ (berturutan $v_{t}$ ) tidak bersifat bebas (not independent) terhadap $x_{t}$ (berturutan $Z_{\mathrm{t}}$ ) pada suatu titik observasi dimana fungsi permintaan kredit (berturutan fungsi penawaran kredit) diamati.

Dengan pertimbangan di atas maka model yang digunakan untuk mengetahui penurunan kredit perbankan pasca krisis apakah lebih disebabkan oleh permintaan kredit atau penawaran kredit adalah model disequilibrium di mana permintaan kredit $\left(\mathrm{L}_{t}^{\mathrm{D}}\right)$ tidak selalu sama dengan penawaran kredit $\left(\mathrm{L}_{t}^{S}\right)^{11}$. Sehingga tingkat kredit aktual $\left(\mathrm{L}_{\mathrm{t}}\right)$ dapat diformulasikan sebagai berikut:

$$
L_{t}=\min \left(L_{t}^{D}, L_{t}^{S}\right)
$$

11 Dalam model ini hanya melihat hubungan antar variabel pada suatu periode observasi tertentu dan belum memperhitungkan faktor jarak waktu (lag). 
- apabila $L_{t}{ }^{D}>L_{t}^{S}$, maka terjadinya penurunan penyaluran kredit aktual $\left(L_{t}\right)$ disebabkan oleh fungsi penawaran kredit, dan

- sebaliknya jika $L_{t}^{D}<L_{t}^{S}$, maka terjadinya penurunan penyaluran kredit aktual $\left(L_{t}\right)$ lebih dipengaruhi oleh fungsi permintaan.

Dalam hal ini model umum penawaran kredit $\left(\mathrm{L}_{t}^{\mathrm{S}}\right)$ diformulasikan sebagai berikut:

$L_{t}^{S}=\alpha_{0}+\alpha_{1} K A P B U_{t}+\alpha_{2} R C R B U_{t}+\alpha_{3} R S B I_{t}+\alpha_{4} N P L_{t}+\alpha_{5} D U M M Y_{t}+\varepsilon_{t}$

dimana :

$\mathrm{L}_{\mathrm{t}}^{\mathrm{s}}=\mathrm{CRBU} \quad:$ total kredit yang disalurkan oleh bank umum

KAPBU

: kapasitas kredit (lending capacity) bank umum

RCRBU : suku bunga kredit bank umum

RSBI : suku bunga SBI

NPL : non performing loan

DUMMY : dummy variabel, bernilai 0 untuk periode Januari 1993 s.d. Juni 1997, dan bernilai 1 untuk periode Juli 1997 s.d. Desember 2003

$\alpha_{0^{\prime}}, \alpha_{1}, \alpha_{2^{\prime}} \alpha_{3^{\prime}} \alpha_{4^{\prime}} \alpha_{5} \quad$ merupakan parameter yang akan diestimasi melalui ML.

$\mathrm{t} \quad$ : periode observasi (bulan ke-t)

Secara teoritis hubungan antara variabel bebas dengan penawaran kredit $\left(\mathrm{L}_{t}^{\mathrm{s}}\right)$ di atas:

- Kapasitas kredit (KAPBU) diharapkan berkorelasi positif dengan penawaran kredit.

- Suku bunga kredit (RCRBU) diharapkan mempunyai hubungan positif dengan penawaran kredit.

- Suku bunga Sertifikat Bank Indonesia (RSBI) diharapkan mempunyai hubungan negatif dengan penawaran kredit.

- Non performing loans (NPL) mempunyai hubungan negatif dengan penawaran kredit.

- Variabel dummy diharapkan mempunyai hubungan negatif dengan penawaran kredit, yang berarti krisis akan menyebabkan penurunan penyaluran kredit.

Sementara itu, model umum fungsi permintaan kredit $\left(\mathrm{L}_{t}^{\mathrm{D}}\right)$ diformulasikan sebagai berikut :

$L_{t}^{D}=\beta_{0}+\beta_{i} P D B R I I L_{t}+\beta_{2} S P R D B U_{t}+\beta_{3}$ KURS $_{t}+\beta_{4} I_{H S G_{t}}+\beta_{5}$ INFLMTM $_{t}+\varepsilon_{t}$

dimana :

$\mathrm{L}_{\mathrm{t}}^{\mathrm{D}}=\mathrm{CRBU} \quad$ : total kredit yang disalurkan oleh bank umum

PDBRIIL : produk domestik bruto

SPRDBU : : spread suku bunga kredit dikurangi suku bunga deposito

KURS : nilai tukar rupiah terhadap US dollar 
IHSG

: Indeks Harga Saham Gabungan

INFLMTM

: laju inflasi bulanan

$\beta_{0}, \beta_{1}, \beta_{2}, \beta_{3}, \beta_{4}, \beta_{5}$

merupakan parameter yang akan diestimasi melalui $\mathrm{ML}$

$\mathrm{t}$

periode observasi (bulan ke-t)

secara teoritis hubungan antara variabel bebas dengan permintaan kredit $\left(\mathrm{L}_{t}^{\mathrm{D}}\right)$ di atas diharapkan sebagai berikut :

- Produk Domestik Bruto (PDBRIIL) mempunyai hubungan positif dengan permintaan kredit.

- Spread suku bunga (SPRDBU) diharapkan berkorelasi negatif dengan permintaan kredit.

- Nilai tukar Rupiah terhadap US dollar (KURS) diharapkan berkorelasi negatif dengan permintaan kredit.

- Indeks Harga Saham Gabungan (IHSG) diharapkan berkorelasi positip dengan permintaan kredit.

- Inflasi bulanan (INFLMTM) diharapkan berkorelasi positip dengan permintaan kredit ${ }^{12}$.

Persamaan (III.11), (III.12) dan (III.13) dapat diselesaikan secara simultan dan koefisien-koefisien dalam persamaan permintaan dan penawaran kredit tersebut diestimasi melalui metode maximum likelihood (ML), dan dalam hal ini digunakan bahasa pemrograman TSP versi 4.3. ${ }^{13}$

\section{II.4. Metode Estimasi Maximum Likelihood}

Sebagaimana dikemukakan dalam spesifikasi model, persamaan permintaan kredit $\left(\mathrm{L}_{t}{ }^{\mathrm{D}}\right)$ dan penawaran kredit $\left(\mathrm{L}_{t}^{\mathrm{s}}\right)$ dalam kondisi disequilibrium dapat diselesaikan dalam bentuk persamaan simultan. Model dasar disequilibrium persamaan simultan penawaran kredit dan permintaan tersebut dapat disederhanakan dalam beberapa persamaan sebagai berikut ${ }^{14}$ :

$$
\begin{aligned}
L_{t}^{D} & =X_{t} \beta+u_{t} \\
L_{t}^{S} & =Z_{t} \alpha+v_{t} \\
L_{t} & =\min \left(L_{t}^{D}, L_{t}^{S}\right) \\
\Delta p_{t} & =\gamma\left(L_{t}^{D}, L_{t}^{S}\right)
\end{aligned}
$$

dimana :

$\mathrm{L}_{\mathrm{t}} \quad$ : kuantitas kredit aktual yang disalurkan oleh bank umum

$L_{t}{ }^{D} \quad$ : fungsi permintaan kredit

\footnotetext{
12 Beberapa peneliti menemukan hubungan yang negatif antara inflasi dengan permintaan kredit, dan beberapa peneliti menemukan hubungan yang positif antara inflasi dengan permintaan kredit.

13 Penjelasan lengkap dapat diminta ke penulis.

14 Sebagian besar bersumber dari buku Judge, GG., W.E. Griffiths, R.C. Hill, H. Lutkepohl, dan Tsoung-Chao Lee (1985).
} 
$L_{t}^{s} \quad$ : fungsi penawaran kredit

$X_{t}$ : faktor-faktor (variabel variabel ekonomi) dari fungsi permintaan kredit

$Z_{t} \quad$ : faktor-faktor (variabel variabel ekonomi) dari fungsi penawaran kredit

$\mathrm{a}, \mathrm{b}$ : vektor-vektor dari parameter yang tidak diketahui (unknwon parameters)

$\gamma$ : unknwon positive scalar parameter

$\Delta p_{t}$ : perubahan harga (suku bunga)

$\mathrm{u}_{\mathrm{t}}, \mathrm{v}_{\mathrm{t}}$ : serially and contemporaneously independent with distribution $\mathrm{N}\left(0, \sigma_{\mathrm{u}}^{2}\right)$ dan $\mathrm{N}\left(0, \sigma_{\mathrm{v}}^{2}\right)$.

Permasalahan dalam menyelesaikan persamaan simultan di atas adalah dalam mengestimasi $\alpha, \beta, \gamma, \sigma^{2}{ }_{u}$ dan $\sigma^{2}{ }_{v}$ dengan observasi $X_{t^{\prime}} Z_{t^{\prime}} L_{t}$ dan $p_{t}$ untuk $t=1,2,3, \ldots, T$. Dapat dicatat bahwa tidak adanya kondisi equilibrium maka observasi kuantitas yang diperdagangan di pasar mungkin tidak memenuhi skedul permintaan dan penawaran. Oleh karena itu, $L_{t}^{D}$ dan $L_{t}{ }^{S}$ tidak terobservasi secara lengkap. Model diasumsikan diidentifikasi dengan perbedaan variabel $X_{t}$ dan $Z_{t}$.

Model di atas dapat direformulasikan dengan memperhatikan periode terjadinya kenaikan harga (suku bunga) atau $\Delta p_{t}>0$ dan periode terjadinya penurunan harga (suku bunga) atau $\Delta p_{t}<0$. Dalam periode terjadi kenaikan harga, maka akan terjadi excess demand, sehingga kuantitas kredit aktual akan sama dengan supply. Dengan demikian fungsi persamaan penawaran kredit (persamaan III.15) dapat diestimasi dengan menggunakan kuantitas kredit aktual sebagai variabel terikat (dependent). Sehingga persamaan (III.17) dapat digunakan untuk menyelesaikan fungsi permintaan kredit (III.14) menjadi :

$$
L_{t}=X_{t} \beta-\frac{1}{\gamma} \Delta P_{t}+u_{t} \quad, \Delta P>0
$$

Sebaliknya, dalam periode terjadinya penurunan harga akan terjadi excess supply sehingga kuantitas kredit aktual akan sama dengan demand. Dengan demikian fungsi persamaan permintaan (persamaan III.14) dapat diestimasi dengan menggunakan kuantitas kredit aktual sebagai variabel terikat (dependent). Dalam kasus ini persamaan (III.17) dapat digunakan untuk menyelesaikan fungsi penawaran kredit (III.15) menjadi :

$$
L_{t}=Z_{t} \alpha+\frac{1}{\gamma} \Delta P_{t}+v_{t} \quad, \Delta P<0
$$

Secara ringkas, model disequilibrium menjadi sebagai berikut :

dimana :

$$
L_{t}=X_{t} \beta-\frac{1}{\gamma} g_{t}+u_{t}
$$

$$
g_{t}= \begin{cases}\Delta p_{t} & \text { jika } \Delta p_{t}>0 \\ 0 & \text { otherwise }\end{cases}
$$


dan

$$
L_{t}=Z_{t} \alpha-\frac{1}{\gamma} h_{t}+v_{t}
$$

dimana :

$$
h_{t}= \begin{cases}-\Delta p_{t} & \text { jika } \Delta p_{t}<0 \\ 0 & \text { otherwise }\end{cases}
$$

Dengan model persamaan (III.20) dan (III.21) di atas, parameter-parameter dalam persamaan dapat diestimasi secara konsisten dengan 2SLS dengan cara sebagai berikut :

- pertama-tama dilakukan regresi $g_{t}$ dan $h_{t}$ dengan semua variabel eksogenus $X_{t}$ dan $Z_{t}$ dalam rangka mendapatkan nilai hitung $\hat{g}_{t}$ dan $\hat{h}_{t}$

- Selanjutnya dalam tahap kedua dilakukan regresi $L_{t}$ dengan $X_{t}$ dan $\hat{g}_{t}$ untuk persamaan (II.2.20) dan dilakukan regresi $L_{t}$ dengan $Z_{t}$ dan $\hat{h}_{t}$ untuk persamaan (III.21).

- Estimator 2SLS tersebut walaupun konsisten tetapi "tidak asymptotically efisien" dalam model ini karena tidak adanya restriksi untuk memaksa $\gamma$ yang sama muncul pada kedua persamaan dan lebih lanjut $g_{t}$ dan $h_{t}$ "bukan merupakan fungsi linear" dari variabel eksogenus.

Amemiya (1974) ${ }^{15}$ memperkenalkan metode iteratif untuk mendapatkan estimator maximum likelihood (ML). Mengingat dalam periode $A$ (kenaikan harga) dimana $L_{t}^{D}>L_{t}^{S}$, conditional density $\Delta P_{t}$ dari yang diberikan $\mathrm{L}_{t}$ adalah $N\left(\gamma\left(L_{t}-Z_{t} \alpha\right), \gamma^{2} \sigma_{v}^{2}\right)$, dan dalam periode $\mathrm{B}$ (penurunan harga) dimana $\mathrm{L}_{\mathrm{t}}^{\mathrm{S}}>\mathrm{L}_{\mathrm{t}}^{\mathrm{D}}$, conditional density dari $\Delta P_{t}$ yang diberikan $\mathrm{Lt}$ adalah $N\left(\gamma\left(L_{t}-X_{t} \boldsymbol{\beta}\right), \gamma^{2} \sigma_{u}^{2}\right) \quad$, maka fungsi likelihood adalah :

$$
\begin{aligned}
& \ln \mathrm{I}=\text { const. }-T \ln \gamma-T \ln \sigma_{u}-T \ln \sigma v \\
& -\frac{1}{2 \sigma_{u}^{2}} \sum_{A}\left(L_{t}-X_{t} \beta\right)^{2}-\frac{1}{2 \gamma^{2} \sigma_{v}^{2}} \sum_{A}\left[\Delta p_{t}-\left(L_{t}-Z_{t} \alpha\right)^{2}\right. \\
& -\frac{1}{2 \sigma_{v}^{2}} \sum_{B}\left(L_{t}-Z_{t} \alpha\right)^{2}-\frac{1}{2 \gamma^{2} \sigma_{u}^{2}} \sum_{B}\left[\Delta p_{t}+\left(L_{t}-X_{t} \beta\right)^{2}\right.
\end{aligned}
$$

Dengan mengambil derivatif berkenaan dengan zero yields a set of conditions yang dapat diselesaikan secara gabungan (bersamaan) untuk parameter yang dicari, Amemiya (1974) menunjukkan bahwa persamaan $\alpha$ dan $\beta$ sama dengan estimator $\alpha$ dan $\beta$ dengan nilai g yang diberikan pada persamaan (III.20a) dan (III.21a). Persamaan untuk $\sigma^{2}{ }_{\mathrm{u}}$ dan $\sigma_{\mathrm{v}}^{2}$ merupakan residual sums of squares dari persamaan (III.20a) dan (III.21a), dengan $\gamma$, dibagi dengan T sebagai estimator $\mathrm{ML}$, dan persamaan g adalah : 


$$
T \gamma+\frac{1}{\sigma_{v}^{2}} \sum_{A}\left(L_{t}-\frac{1}{\gamma} P_{t}-Z_{t} \alpha\right)-\frac{1}{\sigma_{u}^{2}} \sum_{B}\left(L_{t}+\frac{1}{\gamma} P_{t}-X_{t} \beta\right) \Delta P_{t}=0
$$

yang merupakan fungsi kuadrat (non linear) dalam $\gamma$.

Permasalahan yang dihadapi dalam estimasi non linear adalah menemukan nilai parameter $\theta$ yang dapat mengoptimalkan fungsi tujuan $F(\theta)$. Algoritma optimisasi iteratif bekerja dengan cara mengambil set of values untuk nilai parameter, sebut $\theta_{(0)}$, kemudian melakukan kalkulasi berdasarkan set of value tersebut untuk mencari nilai parameter yang lebih baik, sebut saja $\theta_{1}$. Proses dilakukan berulang-ulang (iterasi) sampai didapatkan fungsi tujuan yang optimum. Sehingga ada tiga hal penting dalam melakukan optimisasi fungsi non linear yaitu : (i) mendapatkan initial value, (ii) melakukan updating kandidat vektor parameter ( $\theta$ untuk setiap iterasi, dan (iii) melakukan determinasi ketika diperoleh fungsi optimum.

Selanjutnya Amemiya (1974) memperkenalkan prosedur iteratif sebagai berikut :

- Langkah pertama, menggunakan estimasi 2SLS yaitu $\alpha, \beta$, untuk $\sigma^{2}$ dan $\sigma^{2}{ }_{v}$ sebagai initial value estimate.

- Langkah kedua, melakukan substitusi estimasi $\hat{\alpha}, \hat{\beta}, \hat{\sigma}_{u}^{2}$, dan $\hat{\sigma}_{v}^{2}$ ke dalam persamaan (III.23) dan solve untuk positif root $\gamma, \hat{\gamma}$

- Langkah ketiga, menggunakan $\hat{\gamma}$ dalam persamaan (III.20a) dan (III.21a) untuk mendapatkan estimasi least square untuk $\alpha, \beta, \sigma_{u}^{2}$, dan $_{v}^{2}$

- Dilakukan iterasi langkah kedua dan ketiga di atas sampai diperoleh solusi konvergen.

Selanjutnya Amemiya (1974) juga menunjukkan bahwa estimasi maximum likelihood tersebut dapat diselesaikan dengan menggunakan teknis iterasi standard seperti metode Newton-Raphson dengan melakukan proses melinierkan fist order condition pada nilai $\boldsymbol{\vartheta} F / \boldsymbol{\vartheta} \boldsymbol{\theta}=\boldsymbol{O}$ parameter $\theta_{1}$ :

$$
\begin{gathered}
g_{(i)}+H_{(i)}\left(\theta_{(i+1)}-\theta_{(i)}\right)=0 \\
\left.\theta_{(i+1)}=\theta_{(i)}\right)-H_{(i)}^{-1} g_{(i)}
\end{gathered}
$$

dimana : g adalah vektor gradien $\boldsymbol{\vartheta} \boldsymbol{F} / \boldsymbol{\vartheta} \boldsymbol{\theta}$ dan $\mathrm{H}$ adalah matriks Hessien $\boldsymbol{\vartheta}^{2} \boldsymbol{F} / \boldsymbol{\vartheta} \boldsymbol{\theta} \boldsymbol{\vartheta} \boldsymbol{\theta}^{\prime}$

Dalam paper ini penyelesaian model disequlibrium persamaan simultan permintaan dan penawaran kredit dilakukan dengan bantuan software TSP 4.3 yang menyediakan contoh bahasa pemograman switching regression dalam disequlibrium model dengan metode maximum likelihood ${ }^{n 6}$. Berbeda dengan langkah teoritis prosedur di atas, dalam pemograman standar TSP digunakan metode estimasi OLS untuk mendapatkan nilai $\alpha, \beta$, untuk $\sigma^{2}{ }_{u}$ dan $\sigma^{2}{ }_{v}$ yang selanjutnya akan digunakan sebagai "starting values" dalam mengestimasi persamaan maximum 
likelihood. Sedangkan metode iterasi untuk menyelesaikan fungsi non-linear menggunakan metode gradient, dalam hal ini dengan metode $\mathrm{BHHH}$ (Berndt-Hall-Hall-Hausman), dengan pertimbangan sebagai berikut :

- lebih mudah dalam komputasi dan menjamin non-negative definite sepanjang jumlah observasi lebih besar dari total parameter.

- algoritma mengikuti metode Newton-Raphson namun dengan menggantikan negatif Hessian dengan aproksimasi yang terbetuk dari jumlah outer product vektor gradien untuk setiap kontribusi observasi terhadap fungsi tujuan. Untuk log-likelihood function, aproksimasi ini adalah asymptotically ekuivalen terhadap Hessian aktual ketika dievaluasi pada nilai parameter yang memaksimumkan fungsi. Algoritma $\mathrm{BHHH}$ tersebut sesuai untuk mengatasi permasalahan dalam fungsi $\mathrm{ML}^{17}$.

Berdasarkan hasil estimasi maximum likelihood selanjutnya dilakukan pengujian masingmasing koefisien parameter secara parsial dengan melihat nilai t-statistik. Namun demikian dapat dicatat bahwa t-statistik yang dilaporkan lebih merupakan ukuran presisi estimasi parameter individual, bukan formal stastistical significance. Hal ini dikarenakan estimasi covariance matrix yang dihasilkan mungkin tidak tepat (precise). Estimasi covariance matrix adalah aprroximately $-\mathrm{H}$, di mana $\mathrm{H}$ adalah matriks Hessian yang merupakan fungsi tujuan $\mathrm{L}$. Hasil yang sangat tepat diperoleh jika L bersifat kuadratik dengan parameter bebas $K$, yang selanjutnya setelah dilakukan iterasi sebanyak $\mathrm{K}$ atau lebih estimasi covariance matrix akan exactly $-\mathrm{H}$. Namun demikian, log-likelihood dari model tesis ini lebih kompleks daripada fungsi kuadratik, sehingga standard error yang dilaporkan diinterprestasikan sebagai "guide to significance" bukan "precise measure of signifinance. ${ }^{18}$

Setelah dilakukan uji signifikansi t-statistik terhadap nilai koefisien parameter baik untuk persamaan permintaan kredit maupun penawaran kredit tersebut, maka langkah berikutnya adalah mencari estimasi besarnya permintaan kredit $\left(L_{t}^{D}\right)$ dan estimasi besarnya penawaran kredit $\left(L_{t}^{S}\right)$. Hasil kedua estimasi tersebut selanjutnya dibandingkan dan dengan asumsi $L_{t}=\min \left(L_{t}^{D}, L_{t}^{S}\right)$ maka : - apabila $L_{t}^{D}>L_{t}^{S}$ maka terjadinya penurunan penyaluran kredit aktual $\left(L_{t}\right)$ pasca krisis lebih disebabkan oleh fungsi penawaran kredit.

- sebaliknya jika $L^{D}<L^{S}$, maka terjadinya penurunan penyaluran kredit aktual $\left(L_{t}\right)$ pasca krisis lebih dipengaruhi oleh fungsi permintaan kredit.

17 Untuk permasalahan general non linear least square biasanya digunakan metode Gauss-Newton.

18 Blundel-Wignall, A. dan M. Gizycki.1992.Credit Supply and Demand and the Australian Econom. RDP (Research Discussion Paper) No.9208. Economic Research Department, Reserve Bank of Australia. July 1992. 


\section{HASIL DAN PEMBAHASAN}

\section{III.1. Hasil Uji Kestaioneran Data}

Sebelum dilakukan estimasi model dengan Maximum Likelihood maka terlebih dahulu dilakukan prosedur standar untuk menguji apakah data mengandung unit root yang berarti data bersifat tidak stasioner atau sebaliknya data tidak mengandung unit root yang berarti data bersifat stasioner. Untuk menguji kestasioneran data tersebut digunakan uji ADF (Augmented Dickey-Fuller). Hasil uji kestasioneran data dengan test ADF untuk data dalam level dan first difference disajikan dalam Tabel III.1. berikut ini.

\begin{tabular}{|c|c|c|c|c|}
\hline \multirow[t]{2}{*}{ Variabel } & \multirow[t]{2}{*}{ Simbol } & \multicolumn{2}{|c|}{ ADF Test Statistic *) } & \multirow[t]{2}{*}{ Satuan data } \\
\hline & & Level & $\begin{array}{c}\text { First } \\
\text { Difference }\end{array}$ & \\
\hline $\begin{array}{l}\text { Total kredit } \\
\text { bank umum }\end{array}$ & CRBU, & $-0,9820$ & $-3,5648 * * *$ & Rp miliar \\
\hline PDB riil & PDBRIIL & $-2,5453$ & $-4,0581 * * *$ & Rp miliar \\
\hline Inflasi & $\begin{array}{l}\text { IHK } \\
\text { INFLMTM } \\
\text { INFLYOY }\end{array}$ & $\begin{array}{l}-0,1741 \\
-2,3712 \\
-4,2577 \text { *** }\end{array}$ & $\begin{array}{l}-6,7123 * * * \\
-6,6766 * * * \\
-\end{array}$ & $\begin{array}{l}\text { Indeks } \\
\text { Prosentase } \\
\text { Prosentase }\end{array}$ \\
\hline $\begin{array}{l}\text { Suku bunga } \\
\text { kredit }\end{array}$ & $\mathrm{RCRBU}$ & $-4,4505 * * *$ & - & Prosentase \\
\hline $\begin{array}{l}\text { Suku bunga } \\
\text { deposito }\end{array}$ & RDEPBU & $-3,1907 * *$ & - & Prosentase \\
\hline $\begin{array}{l}\text { Suku bunga } \\
\text { SBI }\end{array}$ & RSBI & $-3,5168 * * *$ & - & Prosentase \\
\hline Kapasitas kredit & KAPBU & $-1,5893$ & $-4,5273 * * *$ & Miliar Rupiah \\
\hline $\begin{array}{l}\text { Non } \\
\text { Performing Loan }\end{array}$ & NPL & $-1,7651$ & $-3,0155 * *$ & Prosentase \\
\hline Nilai tukar rupiah & KURS & $-1,2566$ & $-4,9056 * * *$ & Rupiah per USD \\
\hline Harga saham & IHSG & $-2,9896$ ** & - & Indeks \\
\hline
\end{tabular}

Berdasarkan Tabel III.1. di atas terlihat bahwa untuk data-data berkarakteristik posisi (outstanding) maupun flows seperti posisi kredit (Rp miliar), PDB riil (Rp miliar), dan kapasitas kredit (Rp miliar) umumnya tidak stasioner pada data level, namun akan stasioner pada first difference. Sementara itu untuk data yang berkarakteristik pertumbuhan atau prosentase seperti inflasi tahunan (year on year), suku bunga kredit, suku bunga deposito, dan suku bunga SBI (persen per tahun) umumnya stasioner pada data level. Secara umum dalam tesis ini digunakan 
data-data time series. Berdasarkan pendapat Maddala (1989) dalam Ghosh dan Ghosh (1999) kebanyakan dalam literatur model disequilibrium isu-isu mengenai ketasioneran data tidak dibahas secara eksplisit dan model diestimasi pada level dengan alasan estimasi pada first differences akan menyebabkan kehilangan banyak informasi dan estimasi pada level dapat dibenarkan (legitimate) sepanjang determinan penawaran kredit dan permintaan kredit berbentuk vektor kointegrasi. Namun demikian dalam paper ini penulis tetap melakukan prosedur pengujian unit root dengan alasan untuk mendapatkan gambaran awal mengenai karakteristik data.

\section{III.2. Hasil Estimasi (Estimation Result)}

Hasil estimasi Maximum Likelihood terhadap persamaan simultan permintaan kredit dan penawaran kredit Bank Umum dengan asumsi disequilibrium pada periode sampel Januari 1993 s.d. Desember 2003 (sebanyak 132 observasi) menunjukkan bahwa nilai fungsi maximum likelihood adalah sebesar 181,50. Nilai maksimum fungsi likelihood tersebut tercapai setelah dilakukan evaluasi terhadap 236 fungsi dan konvergen setelah dilakukan 66 iterasi. Secara ringkas hasil estimasi parameter fungsi permintaan dan penawaran kredit disajikan pada Tabel III.2.

\section{Tabel III.2. Hasil Estimasi Maximum Likelihood Persamaan Permintaan dan Penawaran Kredit}

\begin{tabular}{|c|c|c|c|}
\hline Variabel & Koefisien & t Statistik ${ }^{19}$ & Tanda Koefisien \\
\hline Permintaan Kredit $\left(L_{t}{ }^{D}\right)$ & & & \\
\hline $\begin{array}{l}\text { Konstanta } \\
\text { PDB } \\
\text { Spread suku bunga } \\
\text { Kurs } \\
\text { IHSG } \\
\text { Inflasi }\end{array}$ & $\begin{array}{l}-8,06645 \\
1,85978 \\
-0,04143 \\
-0,57151 \\
0,19594 \\
0,06457\end{array}$ & $\begin{array}{l}-2,49157 * * * \\
5,78619 * * * \\
-12,6048 * * * \\
-10,5497 * * * \\
1,61858 * \\
6,20494 * * *\end{array}$ & $\begin{array}{l}\text { + (sesuai hipotesa) } \\
\text { - (sesuai hipotesa) } \\
\text { - (sesuai hipotesa) } \\
+ \text { (sesuai hipotesa) } \\
+ \text { (sesuai hipotesa })\end{array}$ \\
\hline Penawaran Kredit $\left(L_{t}^{s}\right)$ & & & \\
\hline $\begin{aligned} & \text { Konstanta } \\
& \text { - } \text { Kapasitas kredit } \\
& \text { - Suku bunga kredit } \\
& \text { - Suku bunga SBI } \\
& \text { - Non performing loan } \\
& \text { _ } \text { Dummy krisis }\end{aligned}$ & $\begin{array}{l}0,74242 \\
0,90027 \\
0,00219 \\
-0,00127 \\
-0,00704 \\
-0,00290\end{array}$ & $\begin{array}{l}7,32421 * * * \\
69,9340 * * * \\
9,16798 * * * \\
-1,57701 * \\
-9,14378 * * * \\
-0,27555\end{array}$ & $\begin{array}{l}\text { + (sesuai hipotesa) } \\
+ \text { (sesuai hipotesa) } \\
\text { - (sesuai hipotesa) } \\
\text { - (sesuai hipotesa) } \\
\text { - (sesuai hipotesa) }\end{array}$ \\
\hline
\end{tabular}

Number of observations : 132

Log of Likelihood Function : 181,50

Convergence Achieved after 66 iterations

236 Function Evaluations

Tanda * berarti signifikan pada level $10 \%$ ( t tabel = 1,28); tanda ** signifikan pada $5 \%(1,64)$; dan tanda *** signifikan pada $1 \%(2,33)$, 
Berdasarkan Tabel III.2. di atas, dalam fungsi permintaan kredit, seluruh variabel yaitu Produk Domestik Bruto (PDB), spread suku bunga (suku bunga kredit dikurangi suku bunga deposito), kurs Rupiah terhadap USD, Indeks Harga Saham Gabungan (IHSG) dan inflasi secara statistik signifikan mempengaruhi permintaan kredit dan seluruh koefisien mempunyai tanda (sign) sesuai dengan apa yang diharapkan, yaitu :

- Produk Domestik Bruto (PDB) memiliki hubungan yang searah (positif) dan signifikan terhadap permintaan kredit, yang berarti bahwa meningkatnya pertumbuhan ekonomi akan meningkatkan permintaan kredit, dan sebaliknya dalam kondisi perekonomian yang melemah (resesi) maka permintaan kredit cenderung menurun. Hubungan ini mendukung alasan penggunaan variabel ini sebagai proksi penting terhadap permintaan kredit.

- Spread suku bunga memiliki hubungan negatif dan signifikan terhadap permintaan kredit. Artinya semakin tinggi spread suku bunga yang menceminkan semakin mahalnya biaya maka akan menurunkan permintaan kredit, dan sebaliknya semakin rendah spread suku bunga yang mencerminkan semakin murahnya biaya akan meningkatkan permintaan kredit. Fenomena ini mencerminkan bahwa masih tingginya spread suku bunga saat ini menjadi salah satu pertimbangan bagi dunia usaha dalam melakukan permohonan kredit kepada bank.

- Kurs Rupiah terhadap USD memiliki hubungan negatif dan signifikan terhadap permintaan kredit. Artinya melemahnya nilai tukar Rupiah terhadap USD yang mencerminkan kondisi perekonomian yang tidak menentu (uncertainty) sehingga meningkatkan resiko berusaha akan direspon oleh dunia usaha dengan menurunkan permintaan kredit. Sebaliknya menguatnya nilai tukar Rupiah terhadap USD yang mencerminkan stabilitas perekonomian yang semakin mantap akan menurunkan resiko berusaha yang pada akhirnya akan direspon oleh dunia usaha dengan meningkatkan permintaan kredit.

- Indeks Harga Saham Gabungan (IHSG) memiliki hubungan positif dan signifikan terhadap permintaan kredit. Meningkatnya IHSG yang mencerminkan membaiknya kondisi keuangan perusahaan dan kondisi perekonomian yang stabil (certainty) akan meningkatkan minat dunia usaha dalam mengembangkan usaha sehingga akan meningkatkan permintaan kredit. Sebaliknya menurunnya IHSG yang mencerminkan memburuknya kondisi keuangan perusahaan dan kondisi perekonomian yang uncertainty akan mengurangi minat dunia usaha dalam mengembangkan usaha sehingga akan menurunkan permintaan kredit.

- Inflasi memiliki hubungan positif20 dan signifikan terhadap permintaan kredit. Inflasi yang

20 Lihat Blundel Wignal dan Gizycki (1992) dalam "Credit Supply and Demand and the Australian Economy" yang menganggap inflasi sebagai ekspektasi terhadap kenaikan harga-harga relatif barang dan jasa di masa datang yang akan menyebabkan kenaikan jumlah permintaan kredit. 
mencerminkan ekspektasi terhadap kenaikan harga-harga relatif barang dan jasa di masa datang akan menyebabkan kenaikan jumlah kredit yang diminta.

Sementara dalam fungsi penawaran kredit, seluruh variabel (kecuali variabel dummy krisis) yaitu kapasitas kredit, suku bunga kredit, suku bunga SBI, dan Non Performing Loan (NPL) secara statistik juga signifikan mempengaruhi penawaran kredit dan seluruh koefisien variabel bebas (termasuk variabel dummy krisis) mempunyai tanda (sign) sesuai dengan apa yang diharapkan, yaitu :

- Kapasitas kredit (lending capacity) memiliki tanda yang positif. Semakin meningkat kapasitas kredit maka kemampuan bank untuk menyalurkan kredit akan semakin meningkat. Sebaliknya semakin menurun kapasitas kredit maka kemampuan bank untuk menyalurkan kredit semakin berkurang. Hasil ini mendukung hipotesa bahwa kredit yang diberikan sangat tergantung pada kapasitas kredit yang tersedia di bank.

- Suku bunga kredit memiliki koefisien yang positif dan signifikan. Hal ini sesuai dengan hukum penawaran pasar dimana semakin tinggi harga, yang dicerminkan oleh meningkatnya suku bunga kredit, maka semakin banyak kredit yang ditawarkan oleh bank. Sebaliknya semakin rendah harga, yang dicerminkan oleh menurunnya suku bunga kredit, maka semakin sedikit kredit yang ditawarkan oleh bank.

- Suku bunga SBI memiliki koefisien yang negatif dan signifikan. Hal ini berarti bahwa kebijakan moneter ketat yang ditempuh oleh otoritas moneter dengan menaikkan suku bunga SBI maka akan menyebabkan semakin meningkatnya dana perbankan yang ditanamkan pada instrumen SBI sehingga jumlah kredit yang ditawarkan semakin berkurang. Sebaliknya kebijakan moneter longgar yang ditempuh oleh otoritas moneter dengan menurunkan suku bunga SBI maka akan semakin menurunkan penanaman dana perbankan pada instrumen SBI sehingga jumlah kredit yang ditawarkan semakin meningkat. Fenomena ini menggambarkan bahwa SBI merupakan alternatif penanaman aktiva produktif bank selain kredit dan bersifat risk free.

- Non Performing Loan (NPL) memiliki hubungan negatif dan signifikan. Semakin tinggi NPL yang dimiliki bank, maka semakin menurun kredit yang dapat disalurkan. NPL yang tinggi menyebabkan bank harus membentuk cadangan penghapusan yang lebih besar sehingga dana yang dapat disalurkan lewat pemberian kredit semakin berkurang. Sebaliknya semakin rendah NPL yang dimiliki bank, maka semakin meningkat kredit yang dapat disalurkan. NPL yang rendah menyebabkan bank membentuk cadangan penghapusan yang lebih sedikit sehingga dana yang dapat disalurkan lewat pemberian kredit semakin meningkat.

- Variabel dummy krisis memiliki hubungan negatif namun tidak cukup signifikan. Hal ini mengindikasikan bahwa walaupun krisis berdampak terhadap penurunan penyaluran kredit namun pengaruhnya tidak cukup signifikan. 


\section{III.3. Disequilibrium Dalam Pasar Kredit di Indonesia}

Sebagaimana dijelaskan dalam bab sebelumnya, paper ini menggunakan pendekatan new-Keynesian yang mengemukakan bahwa pasar keuangan, seperti pasar kredit, seringkali tidak berfungsi secara sempurna sehingga pasar dalam kondisi disequilibrium. Untuk menjawab asumsi terjadinya disequilibrium dalam pasar kredit di Indonesia tersebut maka dilakukan perhitungan prosentase kelebihan demand terhadap supply (percentage by which demand exceeds supply) sebagaimana yang dilakukan oleh Blundell-Wignall dan Gizycki (1992) dan Pazarbasioglu (1997). Hasil perhitungan prosentase kelebihan demand terhadap supply disajikan dalam Grafik III.1. di bawah ini.

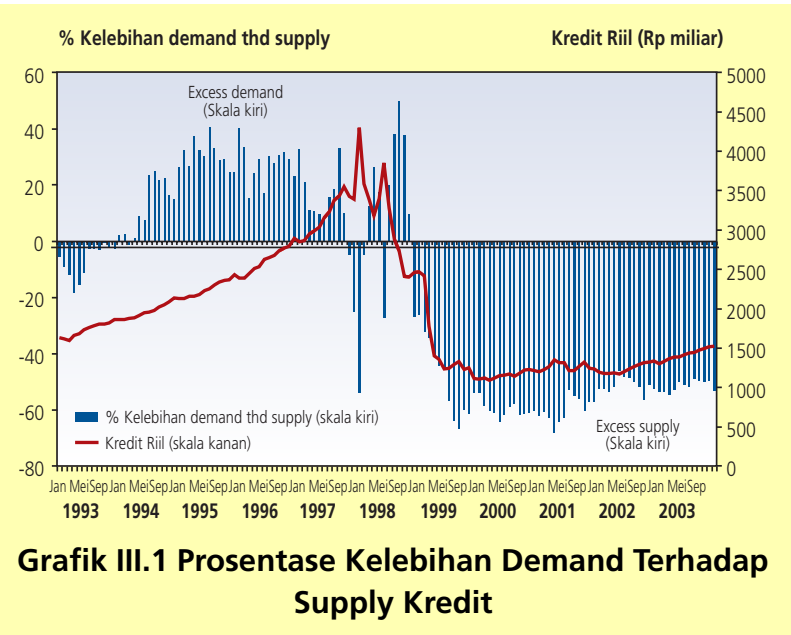

Berdasarkan Grafik III. 1. tersebut di atas terlihat bahwa secara umum pada periode sebelum krisis 1997 terjadi excess demand yang sangat besar (permintaan kredit melebihi penawaran kredit) dan pada periode setelah krisis 1997 terjadi excess supply yang sangat besar. Hal itu membuktikan bahwa dalam pasar kredit di Indonesia terjadi disequilibrium di mana permintaan kredit tidak selalu sama dengan penawaran kredit. Pada periode sebelum krisis, seiring dengan booming ekonomi, permintaan kredit tumbuh sangat pesat, tercermin oleh angka LDR (Ioan to deposit ratio) yang melebihi 100\%. Sebaliknya pada periode setelah krisis, ketika kemampuan bank untuk menyalurkan kredit cepat mengalami pemulihan sebagaimana level sebelum krisis, permintaan kredit tidak terlalu kuat berkaitan dengan masih belum pulihnya perekonomian seperti level sebelum krisis sehingga terjadi excess supply.

Sementara itu hasil temuan Blundell-Wignall dan Gizycki (1992) untuk kasus Australia menunjukkan bahwa selama periode 1982 - 1983 terjadi excess demand yang besar atau terjadi credit rationing yang mencerminkan pasar kredit di Australia pada periode tersebut 
mengalami disequilibrium. Hal ini karena pasar kredit masih dalam proses transisi dari kondisi sebelumnya yang penuh dengan regulasi. Setelah sistem keuangan diliberalisasi pada pertengahan tahun 1982 yaitu dengan dihapuskannya interest ceiling pada simpanan bank dan dihapuskannya kredit langsung, excess demand dan excess supplysejak tahun 1984 mengecil (berkisar 1-2 persen) sehingga pasar menuju kondisi equilibrium. Dengan demikian dapat disimpulkan bahwa liberalisasi sistem keuangan di Australia menyebabkan pasar kredit menjadi sempurna dan terjadi keseimbangan antara penawaran kredit dan permintaan kredit.

Implikasi penting temuan paper ini dibandingkan temuan Blundell-Wignall dan Gizycki (1992) di Australia tersebut adalah masih belum sempurnanya pasar kredit di Indonesia walaupun Indonesia juga telah menempuh liberalisasi sistem keuangan pada tahun 1983. Sebagaimana diketahui, sebelum tahun 1983 sistem keuangan Indonesia dicirikan oleh kurangnya persaingan antara bank dimana bank BUMN menguasai $83 \%$ total aset ${ }^{21}$. Kebijakan moneter yang dilakukan melalui pagu kredit dan restriksi jumlah bank, secara efektif menghambat bank non BUMN dan membatasi perkembangan pasar uang. Suku bunga deposito dan kredit dikontrol secara ketat oleh Bank Indonesia. Untuk memperbaiki sistem keuangan tersebut Indonesia melakukan deregulasi diawali dengan penghapusan kontrol suku bunga dan pagu kredit bank dalam tahun 1983 (PAKJUN 1983). Kemudian dilakukan liberalisasi izin pembukaan bank baru dan cabang bank, penurunan Reserve Requirement (RR), dan penurunan kredit program langsung dalam tahun 1988 (Paket Oktober 1988). Namun demikian dipicu oleh krisis beberapa bank ${ }^{22}$ dan persaingan tidak sehat, Pemerintah melalui Paket Februari 1991 (PAKFEB 1991) mengalihkan fokus kebijakan dengan lebih menekankan pada sistem pengaturan dan pengawasan perbankan. Selanjutnya pada tahun 1992 melalui Undang-undang Perbankan No. 10 / 1992 (Maret 1992) Pemerintah melakukan reregulasi terhadap kegiatan perbankan. Berdasarkan kronologis terjadinya pasang surut dalam deregulasi sistem keuangan di Indonesia tersebut maka dapat dipahami jika pasar kredit di Indonesia dalam keadaan disequilibrium sebagaimana telah dibuktikan dalam paper ini.

\section{III.4. Analisis Penurunan Kredit Pasca Krisis : Penawaran vs Permintaan Kredit}

Untuk memperoleh gambaran apakah menurunnya kredit aktual $\left(\mathrm{L}_{\mathrm{t}}\right)$ setelah krisis lebih dipengaruhi oleh faktor penawaran kredit $\left(L_{t}^{S}\right)$ atau oleh permintaan kredit $\left(L_{t}^{D}\right)$, dilakukan estimasi terhadap jumlah penawaran kredit dan permintaan kredit berdasarkan koefisien yang diperoleh lewat estimasi Maximum Likelihood. Setelah diperoleh estimasi penawaran kredit

21 Saat ini sebanyak 15 bank besar (dari sekitar 133 bank umum yang ada) menguasai aset bank di Indonesia sebesar $85 \%$, sehingga hal ini juga mencerminkan masih timpangnya struktur penguasaan aset bank di Indonesia.

22 Krisis Bank Duta (mengalami kerugian di pasar valuta asing yang sangat besar) dan Bank Summa (yang akhirnya dilikuidasi). 
dan permintaan kredit maka kedua fungsi tersebut ditampilkan pada satu grafik (lihat Grafik III.2 di bawah). Dengan asumsi $\mathrm{L}_{\mathrm{t}}=\min \left(\mathrm{L}_{\mathrm{t}}^{\mathrm{D}}, \mathrm{L}_{\mathrm{t}}^{\mathrm{S}}\right)$ maka :

- apabila $L_{t}^{D}>L_{t}^{S}$ observasi terjadinya penurunan penyaluran kredit aktual $\left(L_{t}\right)$ lebih disebabkan oleh fungsi penawaran kredit, atau

- sebaliknya jika $L^{D}<L^{S}$, maka observasi terjadinya penurunan penyaluran kredit aktual $\left(L_{t}\right)$ lebih dipengaruhi oleh fungsi permintaan kredit.

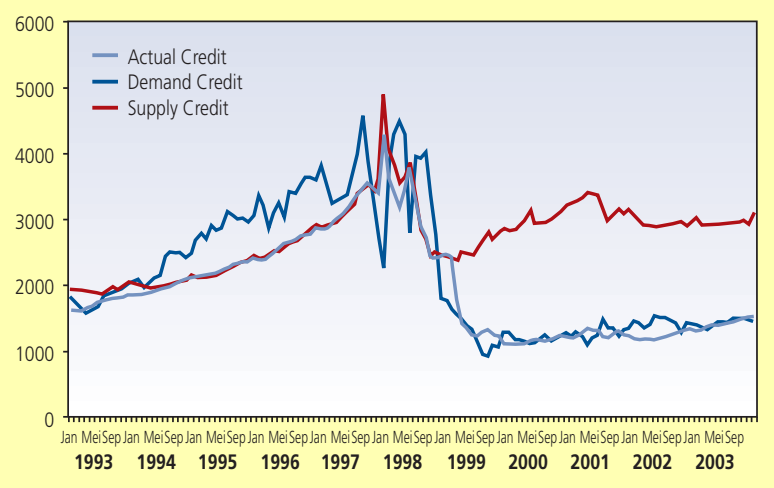

Grafik III.2

Berdasarkan Grafik III.2. tersebut di atas secara umum terlihat gambaran faktor-faktor yang mempengaruhi penyaluran kredit sebagai berikut :

- Pada periode sebelum krisis (1993 s.d. 1996) di mana perekonomian mengalami booming, penyaluran kredit perbankan lebih banyak didorong oleh permintaan kredit (demand driven). Seiring dengan booming perekonomian Indonesia periode 1993 s.d. 1996, kredit perbankan mengalami pertumbuhan yang relatif cepat rata-rata sebesar 25,58\% per tahun, atau lebih tinggi dari pertumbuhan lending capacity sektor perbankan yang tumbuh sebesar $22,05 \%$ per tahun. Pertumbuhan kredit yang pesat di atas pertumbuhan lending capacity tercermin dari tingginya tingkat LDR selama periode tersebut yakni mencapai rata-rata $108,72 \%$. Keadaan tersebut didorong oleh euphoria, keadaan yang mengagumkan karena pertumbuhan ekonomi yang tinggi dalam kurun waktu lama, yang digambarkan sebagai economic miracle oleh Bank Dunia ${ }^{23}$. Lebih lanjut Djiwandono (2001) mengemukakan bahwa masih dominannya peran perbankan dalam perekonomian Indonesia menyebabkan dunia usaha dan masyarakat sering terlalu menggantungkan diri pada jasa perbankan (kredit) untuk membiayai kegiatan-kegiatan mereka. Dalam keadaan 
terlalu dominannya peran perbankan, prinsip kehati-hatian (prudential) sering ditinggalkan baik oleh perbankan maupun oleh dunia usaha dan masyarakat umum. Semua pihak highly leveraging dalam pembiayaan kegiatan, perbankan bekerja dengan modal minimum dan dunia usaha mempunyai debt to equity ratio (rasio utang terhadap modal) yang terlalu tinggi. Sehingga masyarakat hidup melebihi kemampuan baik dalam kegiatan konsumsi, produksi maupun investasi dan perdagangan atau dengan kata lain masyarakat hidup dalam kondisi "lebih besar pasak dari tiang". Temuan empiris paper ini sejalan dengan fenomena penyaluran kredit secara aktual pada periode sebelum krisis tersebut, di mana tingginya pertumbuhan kredit dipicu oleh kuatnya permintaan kredit pada saat itu yang melebihi penawaran kredit.

- Sepanjang krisis 1997/1998, menurunnya penyaluran kredit disebabkan oleh menurunnya kemampuan bank (lending capacity) dalam menyalurkan kredit sehingga jumlah penawaran kredit lebih kecil daripada permintaan. Sehingga dapat disimpulkan bahwa penurunan kredit aktual yang terjadi pada periode krisis tersebut lebih disebabkan oleh faktor penawaran kredit atau terjadi credit crunch. Krisis nilai tukar yang terjadi mengakibatkan memburuknya kemampuan perusahaan dan pada gilirannya meningkatkan kredit bermasalah dalam sistem perbankan karena banyaknya kredit macet. Sementara itu, bank juga menghadapi permasalahan akibat besarnya pasiva dalam denominasi valas yang dimiliki yang sangat rentan terhadap gejolak nilai tukar. Fenomena ini bermula dari permasalahan likuiditas perbankan yang antara lain disebabkan oleh terjadinya bank run dan meningkatnya kewajiban luar negeri. Sementara itu, tingginya suku bunga juga telah menyebabkan terjadinya negative interest margin pada perbankan. Hal ini pada gilirannya telah menurunkan modal perbankan secara drastis. Dalam kondisi capital constrained, wajar jika bank-bank kemudian bertahan untuk tidak menyalurkan kredit, karena kenaikan kredit yang disalurkan akan menambah aset berisiko sehingga mengharuskan bank menambah modal untuk memenuhi ketentuan CAR (Capital Adequacy Ratio). Fenomena ini sering disebut sebagai capital crunch untuk menggambarkan fenomena turunnya kemampuan bank menyalurkan kredit sebagai akibat menurunnya permodalan. Selain itu, krisis yang terjadi sejak pertengahan 1997 berakibat pada melambatnya pertumbuhan DPK yang pada gilirannya berdampak terhadap menurunnya pertumbuhan lending capacity perbankan sehingga mengurangi kemampuan bank dalam menyalurkan kredit. Temuan empiris paper ini sejalan dengan fenomena penurunan kredit secara aktual yang disebabkan adanya credit crunch pada periode krisis, sebagaimana temuan Ghosh dan Ghosh (1999) dan Yuda Agung dkk (2001).

- Pada periode setelah krisis (1999 s.d. sekarang), terjadi excess supply atau kelebihan penawaran kredit bank dibandingkan permintaan kredit, sehingga dapat disimpulkan bahwa penurunan kredit (melemahnya penyaluran kredit) yang terjadi setelah krisis sampai dengan tahun 2003 
(periode akhir observasi) lebih disebabkan oleh masih lemahnya permintaan kredit. Di sisi permintaan, nilai tukar yang semakin terdepresiasi saat krisis disertai suku bunga yang tinggi untuk mengatasi krisis telah melemahkan neraca perusahaan sehingga mengurangi kemampuan investasi di masa mendatang. Hal ini pada gilirannya direspon oleh perusahaan dengan mengurangi permintaan kredit. Faktor lain adalah dalam kondisi masih berlangsungnya pemulihan ekonomi (catatan : pertumbuhan ekonomi setelah krisis belum bisa mencapai level sebelum krisis), penurunan kredit perbankan dapat juga terjadi karena melemahnya permintaan akibat rendahnya prospek investasi (investment opportunities) dan belum pulihnya kondisi keuangan perusahaan non-keuangan. Di sisi penawaran, sejalan dengan meningkatnya kepercayaan masyarakat pada sistem perbankan karena adanya program penjaminan pemerintah, lending capacity secara cepat mengalami proses pemulihan sejak pertengahan 1999 karena didorong oleh meningkatnya Dana Pihak Ketiga (DPK)24 pada bank. Selain itu, adanya program rekapitalisasi perbankan mulai bulan Mei 1999 untuk mengatasi modal bank yang negatif telah meningkatkan kemampuan bank untuk menyalurkan kredit. Temuan empiris paper ini menunjukkan bahwa meskipun kemampuan bank untuk menyalurkan kredit mengalami peningkatan namun belum sepenuhnya mampu diserap oleh sektor riil sehingga terjadi excess supply. Hal ini tercermin dari rendahnya tingkat LDR setelah periode krisis yakni di bawah 50\%. Selain itu, masih melemahnya sisi permintaan kredit tersebut juga dapat dilihat dari besarnya undisbursed loan ${ }^{25}$ karena masih belum bergairahnya ekonomi dan relatif rendahnya proyek yang bankable. ${ }^{26}$

\section{KESIMPULAN DAN SARAN}

\section{IV.1. Kesimpulan}

- Krisis ekonomi tahun 1997 mengakibatkan menurunnya penyaluran kredit secara tajam dan hingga saat ini angka Loan to Deposit Ratio (LDR) masih di bawah 50\% atau separuh dari level sebelum krisis. Hal ini mencerminakan masih belum pulihnya fungsi intermediasi perbankan dalam menyalurkan kredit ke dunia usaha.

- Hasil empiris menunjukkan bahwa penurunan penyaluran kredit dapat dibagi menjadi dua episode. Pertama, periode sepanjang krisis 1997/1998 ditandai dengan excess demand sehingga dapat disimpulkan bahwa penurunan kredit aktual yang terjadi pada periode tersebut lebih disebabkan oleh melemahnya penawaran kredit (credit crunch). Krisis yang terjadi berakibat pada melambatnya pertumbuhan DPK yang pada gilirannya menurunkan

24 DPK merupakan dana yang berhasil dihimpun oleh perbankan dari masyarakat berupa giro, tabungan dan deposito.

25 Kredit yang sudah disepakati antara perbankan dengan debitur namun tidak jadi / belum ditarik oleh debitur yang bersangkutan.

26 Bank Indonesia.2004.Laporan Triwulanan Perkembangan Moneter, Sistem Pembayaran, dan Perbankan Vol.4, No.1, Januari - Maret 2004, hlm. 54. 
lending capacity bank sehingga mengurangi kemampuan bank dalam menyalurkan kredit. $\underline{\text { Kedua }}$, periode setelah krisis tahun 1999 s.d. sekarang ditandai dengan excess supply sehingga dapat disimpulkan bahwa penurunan kredit yang terjadi hingga saat ini lebih disebabkan oleh masih lemahnya permintaan kredit. Dalam kondisi masih belum pulihnya perekonomian sebagaimana level sebelum krisis, lemahnya permintaan kredit merupakan konsekuensi logis dari lemahnya sisi permintaan akibat rendahnya prospek investasi.

- Terjadinya excess supply di pasar kredit sampai saat ini dapat dijelaskan ke dalam dua faktor. Pertama, sudah membaiknya dan menguatnya sisi penawaran kredit oleh perbankan. Pulihnya kepercayaan terhadap sistem perbankan dengan adanya program penjaminan pemerintah telah mendorong kenaikan Dana Pihak Ketiga (DPK) yang pada gilirannya meningkatkan lending capacity perbankan. Selain itu, program rekapitalisasi perbankan mampu mengatasi permasalahan modal bank sehingga telah meningkatkan kemampuannya untuk menyalurkan kredit. Selanjutnya berkurangnya non performing loan (NPL) juga telah meningkatkan kemampuan bank dalam memberikan kredit.

Kedua, masih belum pulihnya sisi permintaan kredit oleh dunia usaha. Melemahnya nilai tukar secara tajam saat krisis disertai suku bunga yang tinggi untuk mengatasi krisis berdampak pada melemahnya neraca perusahaan sehingga mengurangi kemampuan investasi di masa mendatang dan pada gilirannya mengurangi permintaan kredit. Faktor lain adalah dalam kondisi masih berlangsungnya pemulihan ekonomi, penurunan kredit perbankan dapat juga terjadi karena melemahnya permintaan akibat rendahnya prospek investasi dan belum pulihnya kondisi keuangan dunia usaha. Selain itu, masih tingginya spread suku bunga saat ini berpengaruh terhadap lemahnya permintaan kredit. Masih lemahnya permintaan kredit juga tercermin dari masih besarnya undisbursed loan saat ini.

- Implikasi penting lain terhadap temuan empiris adalah terjadinya ketidakseimbangan (disequilibrium) dalam pasar kredit di Indonesia yang dicerminkan oleh sangat besarnya excess demand maupun excess supply sehingga penawaran kredit tidak selalu sama dengan permintaan kredit. Hal ini salah satunya disebabkan adanya informasi yang tidak simetris dalam pasar kredit. Faktor lain, pasang surut dalam reformasi sistem keuangan, di mana deregulasi sektor perbankan terkadang hasilnya tidak sesuai harapan sehingga perlu dilakukan koreksi melalui reregulasi, juga telah menyebabkan pasar kredit tidak bekerja secara sempurna (imperfect market).

\section{IV.2. Implikasi Kebijakan}

- Hasil empiris menunjukkan bahwa masih belum pulihnya pertumbuhan ekonomi saat ini seperti level semula sebelum krisis telah menyebabkan rendahnya permintaan kredit sehingga 
jumlah kredit aktual masih belum dapat mencapai level sebelum krisis. Implikasi penting dari temuan ini adalah perlunya menerapkan kebijakan makroekonomi tepat sesuai dengan sumber output loss, dan meningkatkan efektivitas kebijakan makroekonomi dan struktural dalam menstimulus potential output dan mengurangi berbagai distorsi. Membaiknya perekonomian secara langsung akan merupakan mesin pendorong kenaikan permintaan kredit.

- Secara tidak langsung, membaiknya fundamental perekonomian berarti mengurangi kondisi ketidakpastian (uncertainty) yang akan berpengaruh terhadap : (i) stabilitas nilai tukar rupiah; (ii) kenaikan IHSG, dan (iii) penurunan risiko sehingga menurunkan spread suku bunga, yang pada gilirannya akan mendorong peningkatan permintaan kredit.

- Hasil empiris juga menunjukkan besarnya pengaruh nilai tukar rupiah terhadap permintaan kredit. Implikasi penting dari temuan tersebut adalah perlunya menciptakan stabilitas nilai tukar dengan segera. Hasil ini didukung oleh survei dimana mayoritas pengusaha memilih stabilitas nilai tukar rupiah sebagai hal prioritas dalam rangka pengajuan permintaan kredit. Nilai tukar rupiah yang stabil akan menciptakan kondisi kepastian dalam berusaha sehingga memudahkan pengusaha dalam merencanakan kegiatan usaha dan menentukan harga produksi.

- Hasil empiris juga menunjukkan bahwa pasar kredit dalam kondisi disequilibrium sehingga suku bunga tidak cukup fleksibel untuk menyeimbangkan permintaan kredit dengan penawaran kredit. Tidak bekerjanya pasar kredit secara sempurna menyebabkan transmisi kebijakan moneter melalui jalur suku bunga menjadi kurang efektif. Kebijakan moneter ekspansi yang ditempuh Bank Indonesia untuk menurunkan suku bunga SBI secara cepat selama beberapa tahun terakhir tidak serta merta diikuti dengan menurunnya suku bunga kredit secara cepat. Hal ini pada gilirannya menyebabkan kebijakan moneter ekspansif tersebut kurang efektif dalam mendorong permintaan kredit.

- Dalam situasi dimana bank mengalami ekses likuiditas dan portofolio aset perbankan mengalami pergeseran dari kredit ke penempatan Surat Berharga (SBI dan Obligasi Negara) hingga saat ini, kebijakan moneter Bank Indonesia akan menjadi dilematis. Di satu sisi, kebijakan moneter longgar yang berarti menurunkan suku bunga SBI akan mengakibatkan bank-bank "terpaksa" mengurangi penempatan surplus dananya pada SBI. Namun dalam kondisi bahwa disintermediasi perbankan lebih disebabkan masih lemahnya sisi permintaan kredit maka hal tersebut akan meningkatkan excess supply kredit, karena meningkatnya jumlah penawaran kredit tidak mampu diserap oleh permintaan kredit dari sektor riil. Di sisi lain, kebijakan moneter ketat yang berarti akan meningkatkan suku bunga SBI maka akan menyebabkan bank lebih banyak menempatkan dananya pada SBI sehingga mengurangi penyaluran kreditnya yang pada gilirannya akan menyebabkan pemulihan fungsi intermediasi perbankan menjadi terhambat. 
- Menghadapi permasalahan yang dilematis tersebut, menurut hemat penulis perlu dilakukan langkah-langkah kompromi dalam kebijakan moneter. Dalam kerangka inflation targeting, sasaran tunggal kebijakan moneter tetap diarahkan pada laju inflasi jangka menengah dan panjang yang cukup rendah dan stabil. Namun demikian kebijakan perlu dilakukan secara hati-hati dengan tetap menjaga proses pemulihan ekonomi yang masih sedang berlangsung. Terjemahan sederhananya adalah dalam situasi di mana terjadi excess likuiditas kebijakan moneter lebih dititikberatkan pada pengendalian laju pertumbuhan uang beredar, dibandingkan menaikkan suku bunga. Hal ini karena dalam situasi perbankan mengalami kelebihan likuiditas, maka masih mungkin dilakukan pengetatan uang beredar tanpa kenaikan suku bunga yang signifikan. Dengan demikian di satu sisi proses pemulihan ekonomi tetap terjaga sehingga dapat mendorong kenaikan permintaan kredit, di sisi lain pengetatan uang beredar akan berdampak pada stabilitas nilai tukar rupiah yang selanjutnya juga mendorong kenaikan permintaan kredit. Hal ini pada gilirannya akan dapat mengatasi permasalahan disintermediasi saat ini yang lebih disebabkan oleh lemahnya permintaan kredit.

\section{IV.3. Saran}

- Temuan empiris menunjukkan terjadinya ketidakseimbangan (disequilibrium) dalam pasar kredit di Indonesia yang dicerminkan oleh sangat besarnya excess demand maupun excess supply. Hal ini salah satunya disebabkan adanya informasi yang tidak simetris dalam pasar kredit dan terjadinya pasang surut dalam reformasi sistem keuangan (pro pasar) yang terkadang dilakukan koreksi melalui reregulasi sehingga pasar kredit tidak bekerja secara sempurna (imperfect market). Penulis menyarankan agar masalah ini perlu dikaji lagi lebih mendalam, sehingga dapat memberikan perbaikan yang lebih konkret misalkan dalam mengatasi informasi yang tidak simetris.

- Penulis menduga bahwa penyebab terjadinya disequilibrium dalam pasar kredit di Indonesia adalah karena tersegmentasinya pasar. Dari sisi supply, tersegmentasinya perbankan di Indonesia terlihat dari adanya pengkotakan/dikotomi antara bank besar vs kecil, bank nasional vs bank regional (BPD), bank devisa vs bank non-devisa, bank asing vs bank domestik, dan lainnya. Sementara dari sisi demand, tersegmentasinya debitur terlihat dari dominannya sektor usaha raksasa (konglomerat) dalam mengajukan permintaan kredit dibandingkan sektor usaha kecil dan menengah (UKM). Penulis menyarankan agar dilakukan studi lebih lanjut terhadap model disequilibrium dengan data yang bersifat disagregat.

- Dalam paper ini kondisi ketidakpastian (uncertainty) yang secara implisit tercermin dari indikator nilai rukar rupiah, spread suku bunga, dan indeks harga saham gabungan terbukti 
dapat mempengaruhi permintaan kredit. Penulis menyarankan agar dilakukan studi lanjut dengan memasukkan variabel ketidakpastian (uncertainty) secara eksplisit dalam model, sehingga nantinya dapat memberikan perbaikan yang lebih konkret misalkan dalam mengatasi kondisi yang tidak pasti.

- Banyak penulis menyatakan bahwa dalam keadaan ketidak sempurnaan informasi para perumus kebijakan seyogyanya jangan mengambil reaksi yang terlalu berkelebihan (over reaction) terhadap permasalahan yang timbul. Dalam kondisi informasi yang tidak sempurna kesalahan langkah sama mungkinnya terjadi dengan ketepatan langkah. Masalah yang dapat timbul dari ketidakpastian tersebut adalah adanya jarak waktu (lag) dari kebijakan yang diambil yaitu inside lag dan outside lag. Kebijakan monerer biasanya memiliki outside lag yang panjang, pengaruhnya datang lambat dan bisa menyebar beberapa tahun ke depan. Di lain fihak kebijakan fiskal mempunyai outside lag lebih pendek karena langsung mempengaruhi pengeluaran masyarakat. Namun karena struktur administrasinya kebijakan fiskal mempunyai inside lag yang panjang, sementara kebijakan moneter mempunyai inside lagyang lebih pendek. Penulis menyarankan agar dilakukan studi lanjut dengan memasukkan unsur lag dalam mode ${ }^{27}$, sehingga nantinya dapat memberikan saran kebijakan yang lebih realistik dengan memperhatikan adanya masalah jarak waktu (lag). 


\section{DAFTAR PUSTAKA}

Agenor, P.R., J. Aizenman, dan A. Hoffmaister. The Credit Crunch in East Asia : What Can Bank Excess Liquid Assets Tell Us?. NBER, Inc., Cambridge. Working Paper 7951. October 2000.

Agung, J., B. Kusmiarso, B. Pramono, E.G. Hutapea, A. Prasmuko dan N.J. Prastowo. Credit Crunch di Indonesia Setelah Krisis : Fakta, Penyebab dan Implikasi Kebijakan. Direktorat Riset Ekonomi dan Kebijakan Moneter, Bank Indonesia. 2001.

A. Koutsoyiannis. Theory of Econometrics. Second edition. The Mac Millan Press Ltd., London and Basingstoke. 1977.

Amemiya, T. A Note on Fair and Jaffee Model. Econometrica . 1974, vol. 42, p.759-762.

Bank Indonesia. Laporan Perekonomian Indonesia 2003. Bank Indonesia, Jakarta. 2003

Bank Indonesia. Perbankan Indonesia Tahun 2002. Bank Indonesia, Jakarta. Juni 2003.

Barajas, A. dan R. Steiner. Credit Stagnation in Latin America. IMF Working Paper No.WP/02/ 53, Maret 2002.

Bernanke, B. and Lown, C. The Credit Crunch. Brooking Paper in Economic Activity. February, 1991.

Bester, Helmut. Screening vs Rationing in Credit Markets with Imperfect Information. American Economic Review. 1985, Vol.75, pp.850-855.

Blundel-Wignall, A. dan M. Gizycki. Credit Supply and Demand and the Australian Economy. RDP (Research Discussion Paper) No.9208. Economic Research Department, Reserve Bank of Australia. July 1992.

Borensztein, E. dan J.W. Lee. Financial Crisis and Credit Crunch in Korea : Evidence from FirmLevel Data. IMF Working Paper No.WP/00/25, Februari 2000.

Demirgiic-Kunt, A., E. Detragiache, dan P. Gupta, P. Inside the Crisis : An Empirical Analysis of Banking System in Distress. IMF Working Paper No.WP/00/156, Oktober 2000.

Ding, W., I. Domac dan G. Ferri. Is There a Credit Crunch in East Asia. World Bank Working Paper. 1998.

Domac, I, and Ferri, G. The real impact of financial shocks: evidence from the Republic of Korea. 1998. World Bank - Policy Research Working Paper Series, No.2010. 
Fair, R.C. dan H.H. Kelejian. Methods of Estimation for Markets in Disequilibrium : A Further Study. Econometrica, Vol.42, No.1, Januari 1974, hlm. 177-190.

Falianty, T.A. Exchange Rate Overshooting : Sebuah Studi Empiris di Indonesia dalam Sistem Nilai Tukar Mengambang. Tesis. Program Studi Ekonomi, Pasca Sarjana Fakultas Ekonomi Universitas Indonesia, Jakarta. 2003.

Gosh, A. and Gosh, S. East Asia in the Aftermath: Was there a crunch?. IMF Working Paper 1999/38, Maret 1999.

Ito, Takatoshi dan Yuri Nagataki Sasaki. Impacts of the Basle Capital Standard on Japanese Bank's Behaviour. 1998. NBER Working Paper 6730.

J. Soedradjad Djiwandono. Bergulat dengan Krisis dan Pemulihan Ekonomi Indonesia. Pustaka Sinar Harapan, Jakarta. 2001.

Judge, G.G., W.E. Griffiths, R.C. Hill, H. Lutkepohl, dan Tsoung-Chao Lee. The Theory and and Practice of Economterics. Second Edition. John Wileyand Sons, New York. 1985.

Laffont, J-J., and R. Garcia. Disequilibrium Econometrics for Business Loans. Econometrica, Vol.45, No.5, Juli 1997, hlm. 1187-1204.

Lukman Hakim. Perbandingan Peranan Jalur Kredit pada Masa Sebelum dan Ketika Krisis Ekonomi 1990. 1 - 2000.4. Dalam Lukman Hakim, B. Santosa, dan E. Setyaningrum (Editor). Beberapa Agenda Perekonomian Indonesia Kritik dan Solusi. Dewan Riset Fakultas Ekonomi Universitas Trisakti, Jakarta. 2004.

Park, Yung Chul, and Jong Wha Lee. Recovery and Sustainability in East Asia," in Korean Crisis and Recovery, ed. by David T. Coe and Se-Jik Kim. International Monetery Fund, Washington. 2002.

Pazarbasioglu, C. A credit crunch? Finland in the Aftermath of the Banking Crisis. IMF Staff Paper, Vol. 44, No.3, September 1997, hlm. 315-327.

Stiglitz, J.E., dan A. Weiss. Credit Rationing in Markets with Imperfect Information. American Economic Review, 1981. vol.71, pp.393-410.

Woo, David. In Search of "Capital Crunch" : Supply Factors Behind the Credit Slowdown in Japan. IMF Staff Paper No. WP/99/3, Januari 1999.

Yoshikawa, H., E. Eto dan T. Ike. Credit Crunch for Small and Medium Size Firms : Policy Analysis. Series 1. Economic Planning Agency, Tokyo. 1994. 